DOI: http://doi.org/10.31617/k.knute.2019-03-19.54

\title{
МЕДІА-ТЕРОРИЗМ ТА ПРОБЛЕМИ БОРОТЬБИ 3 НИМ У СУЧАСНОМУ СУСПІЛЬСТВІ
}

\author{
Манаєнко Д. Д. \\ студентка 3 курсу \\ кафедра маркетингу \\ Гамова I. B. \\ к.е.н., доцент \\ кафедра журналістики та реклами \\ Київський національний торговельно-економічний університет, \\ Україна
}

Ключові слова: медіа-інформачійний тероризм, терористичний акт, масові комунікаиії, інформаційні війни, терористична свідоMicmb, 3MI.

Keywords: media information terrorism, act of terror, mass communications, infowar, terrorist consciousness, mass media.

Сьогодні існує багато способів маніпуляції завдяки інформації. Маніпулятивні технології набувають дедалі ширшого використання, завдяки їм ведуться інформаційні війни, знищення опонентів, вплив на маси і багато інших дій. Але останнім часом великої популярності набув інформаційний тероризм.

Медіа-тероризм є особливим різновидом психологічного терору, який відносять до інфраструктурного, а саме - зловживання інформаційними системами, мережами та їх компонентами для здійснення терористичних дій та інших віднесених до них акцій.

Інформаційний тероризм здійснюється в області, що охоплює політичні, філософські, правові, естетичні, релігійні й інші погляди й ідеї, тобто в духовній сфері, там, де ведеться боротьба ідей [1].

Інформаційний тероризм - це, насамперед, форма негативного впливу на особистість, суспільство і державу усіма видами інформації.

Його ціль - ослаблення і розхитування конституційного ладу. Він ведеться різноманітними силами і засобами - від агентури іноземних спецслужб до вітчизняних і закордонних ЗМІ. Для здійснення психологічного террору використовуються не лише друковані ЗМІ та мережі ефірних й кабельних мас-медіа, але й Інтернет, електронна пошта, різноманітні електронні іграшки,компакт-диски, аудіокасети тощо. 
У мирний час прямими виконавцями акцій інформаційного тероризму є: іноземні спецслужби й організації; закордонні і значна частина українських 3МІ; окремі екстремістські елементи і групи [2].

Майже 47 років тому відбувся теракт на мюнхенській Олімпіаді. Близько 4:40 ранку 5 вересня 1972 року вісім членів радикального палестинського угруповання «Чорний вересень», одягнені у спортивні костюми, озброєні автоматичною зброєю та гранатами, подолали паркан навколо олімпійського села у Мюнхені і оточили будинок, де мешкала ізраїльска команда. Розстрілявши на місці двох спортсменів, терористи захопили в заручники дев'ятьох спортсменів і двох тренерів.

Протистояння закінчилося перестрілкою із німецькою поліцією, у результаті котрої загинуло п'ять терористів, німецький поліцейський і всі дев'ять ізраїльських заручників. У відповідь на цей теракт ізраїльський уряд провів дві операції з ліквідації учасників нападу. Цей теракт залишається одним 3 найгірших та найтрагічніших в історії Олімпійських ігор [3].

Яскравим представником такого тероризму свого часу в Україні було «Біле братство». Сотні людей підпали під вплив сектантівфанатиків. Такі дії навіть спричинили закриття шкіл на деякий час, люди боялися випускати дітей на вулиці. Мету терористів було досягнуто, в суспільстві панував страх і дестабілізація.

Тероризм, на жаль, став невід'ємною частиною політичних і економічних процесів в світі, і представляє все більш значну загрозу громадській і національній безпеці. Будучи різновидом організованої злочинності які занурюються корінням в потужну тіньову економіку, тероризм може поставити під сумнів весь процес подальшого розвитку людства. Тероризм - це метод впливу шляхом здійснення теракту задля досягнення певних цілей, за якого жертва теракту не $\epsilon$ об'єктом [1-2].

Теракти в 2018 році відбувалися на території Афганістану, США, Сирії, Франції, Нігерії, Іраку, Венесуели, Ірану і Лівії. Відповідальність за більшу частину терактів взяли на себе бойовики Ісламського держави. Незважаючи на збільшення кількості атак, кількість жертв під час терактів стало меншим завдяки підвищеним заходам безпеки [4].

Різновид тероризму характеризується як множина інформаційних війн та спеціальних операцій, пов'язаних із національними або транснаціональними кримінальними структурами й спецслужбами іноземних держав. Доступність інформаційних технологій значно підвищує його ризики, бо чим інформатизованішим є суспільство, тим піддатливіше воно з технологічного погляду до впливів масово- 
психологічного терору. Такий тероризм полягає також у спробах організації спеціальних медіа-кампаній, покликаних зруйнувати знаково-символьну інфраструктуру суспільства, створити атмосферу громадянського хаосу, клімату взаємної недовіри, зумовити поширення ксено-фобних настроїв і підозріле настановлення щодо «чужинців», якими можуть виявитися представники будь-яких меншин.

Загалом, орієнтуючись на низькопробні смаки, електронні масмедіа (й зокрема телебачення) зазвичай схильні не лише до всілякої «полунички», а й до демонстрації сцен насильства й терору з метою збільшення чисельності аудиторії, бо відповідно збільшуються доходи від реклами.

Тед Коппел із американської телекомпанії АВС свого часу слушно зауважив: «Мас-медіа - особливо телебачення - й терористи, вступаючи у відносини спеціальної залежності, потребують одні одних, між ними виникають відносини симбіозу. Без телебачення терорист уподібнився $б$ до філософа, закинутого у лісові нетрі, до голосу якого ніхто не дослухається й докази якого ніким не почуті. Але й телебачення без показу актів терору... втратило б значною мірою інтерес аудиторії».

Створюється хибне коло - демонструючи сцени ігрового або реального терору, мас-медіа нав'язують»терористичну свідомість» з усіма iї наслідками [5].

3 інформаційним тероризмом потрібно боротися вже сьогодні [6]. Він має переслідуватися за законом нарівні $з$ тероризмом звичайним. Спотворюючи факти і фальсифікуючи події, інформаційні терористи впливають на свідомість людей у значно більших масштабах, ніж вибух тротилової бомби, і це призводить до значно трагічніших наслідків.

\section{Список використаних джерел}

1. Інформаційний тероризм як інструмент зовнішньої політики держави на сучасному етапі [Електронний ресурс]. - Режим доступу : URL : http://ena.lp.edu.ua/bitstream/ntb/19234/1/55Ryumina-266-268.pdf. - Назва з екрана.

2. Інформаційний тероризм [Електронний ресурс]. - Режим доступу : URL: http://www.harmony.com.ua/text/149.html. - Назва з екрана.

3. «Чорний вересень» здійснив теракт на Олімпійських іграх [Електронний ресурс]. - Режим доступу : URL : https:/gazeta.ua/articles/ history/_cornij-veresen-zdijsniv-terakt-na-olimpijskih-igrah-42-rokitomu/579374/ - Назва з екрану. 
4. Найбільші теракти 2018 року [Електронний ресурс]. - Режим доступу : URL : https://uk.etcetera.media/naybilshi-terakti-2018-rokude-vidbulisya-i-skilki-lyudey-postrazhdalo.html. - Назва з екрана.

5. Загальні проблеми інформаційної безпеки [Електронний ресурс]. Режим доступу : URL : https://pidruchniki.com/10560412/ politologiya/zagalni_problemi_informatsiynoyi_bezpeki. - Назва 3 екрану.

6. Тероризм і пропаганда у 3МI [Електронний ресурс]. - Режим доступу : URL : https://petrimazepa.com/terrormedia.html. - Назва 3 екрана.

DOI: http://doi.org/10.31617/k.knute.2019-03-19.55

\title{
ДО ПИТАННЯ ПРО ВЗАЕМОДІЮ РЕКЛАМИ ТА РЕКЛАМНӦ̈
} ЖУРНАЛІСТИКИ

\author{
Маренич В. М. \\ к.ю.н., доцент \\ кафедра журналістики та реклами \\ Київський національний торговельно-економічний університет \\ Радченко Л. О. \\ к.і.н., доцент, професор \\ Харківський національний університет ім. В.Н. Каразіна \\ директор \\ Харківський торговельно-економічний коледж КНТЕУ, Украӥна
}

Ключові слова: реклама, види реклами, рекламна журналістика, рекламний медіа текст, журналістські жанри рекламних матеріалів.

Keywords: advertising, types of advertising, advertising journalism, advertising media text, journalistic genres of advertising materials.

Сьогодні реклама пронизала усі сфери життя, стала невід'ємною його частиною, а рекламна діяльність - актуальним напрямом дослідження. В той же час реклама - динамічна сфера людської діяльності, іiі характер, зміст і форма швидко трансформуються під впливом розвитку продуктивних сил суспільства. Масова рекламна атака переслідує сучасну людину всюди і вона їі відчуває щоденно.

Вперше реклама з'явилася в 15 сторіччі - 3 появленням книгодруку. Типографи почали пропагувати свої книги 3 похвальними відгуками на них. Пізніше найбільш розповсюдженим засобом реклами стали оголошення в газетах [1]. В Законі України «Про 